\title{
Continuing Education in Mental Health: Critical Moments to Analyze Group Process $^{1}$
}

\author{
Gabriela Martins Silva ${ }^{2}$, Ottar Ness ${ }^{3}$, Carla Guanaes-Lorenzi ${ }^{2}$ \\ ${ }^{2}$ Universidade de São Paulo, Ribeirão Preto-SP, Brazil \\ ${ }^{3}$ Norwegian University of Science and Technology, Trondheim, Norway
}

\begin{abstract}
In Brazilian context, literature points to Continuing Education in Health $(\mathrm{CEH})$ policy as a means to actualize the Psychiatric Reform. Although it is also a challenge considering its proposal of close connectedness with each context in which it occurs. This study aimed to understand how mental health professionals learn together in CEH-processes, identifying and understanding conversational transformations that occurred in the interactional process. An educational process inspired by the CEH policy was then carried out with a group of eight professionals from a Psychosocial Care Center. This process was analyzed from the notion of critical moments, with a social constructionist stance. In doing so, the critical moment "Sharing the Feeling of Standstill" was delimited considering its effects on the conversational process. With this, it is argued that, even in conversations that seem saturated by problems, it is possible to identify generative moments, as a relational achievement, through dialogue.
\end{abstract}

Keywords: continuing education, mental health, social constructionism

\section{Educação Permanente em Saúde Mental: Momentos Críticos na Análise do Processo Grupal}

\begin{abstract}
Resumo: No contexto brasileiro, a literatura aponta a política de Educação Permanente em Saúde (EPS) como caminho para efetivação da Reforma Psiquiátrica. Contudo, a EPS é também um desafio, considerando sua proposta de estreita ligação com cada contexto no qual ocorre. Assim, este estudo teve como objetivo compreender como profissionais de saúde mental podem aprender conjuntamente em processos de EPS, identificando e entendendo as transformações conversacionais que ocorreram no processo interacional. Realizou-se, então, um processo de educação inspirado na política de EPS, com um grupo de oito profissionais de um Centro de Atenção Psicossocial. Esse processo foi analisado a partir da noção de momentos críticos, com uma orientação construcionista social. Ao fazê-lo, o momento crítico "Compartilhando o sentimento de paralisação" foi delimitado, considerando seus efeitos no processo conversacional. Com isso, discute-se que, mesmo em conversas que parecem saturadas pelos problemas, é possível identificar momentos generativos, construídos relacionalmente, por meio do diálogo.
\end{abstract}

Palavras-chave: educação permanente, saúde mental, construcionismo social

\section{Educación Continua en Salud Mental: Momentos Críticos en el Análisis del Proceso Grupal}

\begin{abstract}
Resumen: La literatura brasileña apunta la política de Educación Continua en Salud (ECS) como camino para la efectivación de la Reforma Psiquiátrica. Sin embargo, la ECS es también un desafío, considerando su propuesta de estrecha relación con cada contexto en el que ocurre. Este estudio tuvo como objetivo entender cómo profesionales de salud mental pueden aprender conjuntamente en procesos de ECS, identificando y entendiendo las transformaciones conversacionales que ocurrieron en el proceso interacional. Se realizó un proceso de educación inspirado en la política de ECS, con un grupo de ocho profesionales de un Centro de Atención Psicosocial. Este proceso fue analizado desde la noción de momentos críticos, con una orientación construccionista social. Al hacerlo, el momento crítico "Compartiendo el sentimiento de paralización" fue delimitado, considerando sus efectos en el proceso conversacional. Con eso, se discute que, incluso en conversaciones que parecen saturadas por los problemas, es posible identificar momentos generativos, construidos relacionalmente, mediante el diálogo.
\end{abstract}

Palabras clave: educación continua, salud mental, construccionismo social

\footnotetext{
${ }^{1}$ Article derived from the doctoral dissertation of the first author under the supervision of the third author, defended in 2017, in the Postgraduate Program in Psychology of the Faculdade de Filosofia, Ciências e Letras de Ribeirão Preto, Universidade de São Paulo. Support: Fundação de Amparo à Pesquisa do Estado de São Paulo (Grant \# 2014/09444-1 and 2016/03467-5)

Correspondence address: Gabriela Martins Silva. Universidade de São Paulo. Faculdade de Filosofia, Ciências e Letras de Ribeirão Preto. Avenida Bandeirantes, 3900. Bairro Monte Alegre. Ribeirao Preto-SP, Brazil. CEP 14.040-901. E-mail: gabrielampsico@gmail.com
}

This article presents an analysis of a group process inspired in the Continuing Education in Health (CEH) Brazilian policy, developed with professionals of public mental health services in Brazil. With this, it is shown how a process of transformation and collaborative learning can occur through an analysis guided by the notion of critical moments.

As a fundamental component of the right to health, mental health is part of Brazilian National Healthcare 
System (Sistema Único de Saúde - SUS), being guided by the Psychiatric Reform, which has been a policy since the enactment of Law 10.216 in 2001. This policy establishes the progressive closure of hospital beds with their replacement by community services. The idea, in this policy, is that people diagnosed with psychiatric disorders can be treated in the community without being removed from their social and family life, by an interdisciplinary approach, facing the stigma of madness and the medical centrality in health practices. This brings significant challenges for professionals of different areas that should transform their practices towards joint action in an integral notion of health, as well as look at the social context, including the patient's family in the care process (Amarante, 2015; Desviat, 2011; Pitta, 2011).

Given its complexity, the effectiveness of the Psychiatric Reform demands important efforts and CEH have being highlighted as a powerful path to face the challenges that are currently present (Campos, 2001; Ceccim, 2010; Pitta, 2011). The importance of continuing education for the field of health has been marked since 1980s by the Pan American Health Organization (Davini, 1995). Nowadays this is still highlighted in the international context as a means to improve health care by promoting interdisciplinarity and seeking to reach patients' expectations and needs, specially through collaborative practices (Turco \& Baron, 2016).

The term CEH was demarcated by the Brazilian Ministry of Health to highlight the distinctive character of the proposal, setting a new policy for the field. It was first established by the ministerial ordinance n. 198 from 2004 and subsequently amended by ministerial ordinance n. 1.996 from 2007 (Gigante \& Campos, 2016; Ministério da Saúde, 2009; Pinto et al., 2014).

The $\mathrm{CEH}$ is taken as a means to promote the necessary changes for ensuring the right to health with integrality, meeting the principles of SUS. The CEH proposes the interrelationship between assistance, management and training in health, putting together work and citizenship (Ceccim \& Feuerwerker, 2004). CEH aims to promote significative and collaborative learning from talking about issues, not in the search for ready and true answers, but aiming the production of collective acts of teaching and learning by reflection (Ceccim, 2010). So, it is not based in classes or training new procedures, but in meetings where professionals can discuss daily challenges, looking together and in an autonomous manner for solutions though conversations and studies.

In this sense $\mathrm{CEH}$ demands critical pedagogical practices, based in the appreciation of knowledge of professionals, in the elements that make sense to them, with focus on everyday dilemmas, that promotes learning how to learn together (Gigante \& Campos, 2016; Ministério da Saúde, 2009; Stroschein \& Zocche, 2011). At the same time, it is important to think about ways to evaluate these educational activities, enabling to give visibility to the importance of the process for the improvement of health practices (Campos, 2015). Thus, to conduct, to analyze, and to evaluate a CEHprocess become a complex but important task. In this sense, social constructionism guidelines to group processes seem to be useful. Social constructionism is a critical approach in psychology and social sciences that puts language and interactional and dialogical processes as central aspect to shape realities and phenomena. Thus, it studies how knowledge is produced in the interaction between people, in their communicational processes, critically analyzing their implications for the construction of ways of living (Gergen, 2015; Gergen \& Ness, 2016; McNamee, 2014).

Dialogue is a central aspect in the social constructionist perspective. It is understood as coordination of actions among people, instead of being taken as communication between individuals of what they have in their minds. When people engage in dialogue, their speech became related in an inextricable way, increasing the possibilities for interrelated actions (Gergen, McNamee, \& Barrett, 2001).

As social constructionism is an epistemology finely tuned with the construction of reality by language use through the relationship between people, which in turn is informed by social-cultural patterns, constructionism brings contributions to general studies and practices that involve communication between people (Gergen \& Ness, 2016; Guanaes-Lorenzi, 2015; Moscheta, Souza, \& Corradi-Webster, 2015).

For educational and group practices like $\mathrm{CEH}$, object of this work, social constructionism is especially useful because in addition to considering the fundamental importance of relationships, it foresees modes of development and organization of the conversation that promote dialogue. This approach helps the promotion of generative moments, in which meanings can be transformed through interaction and dialogue among participants, beginning from the recognition that there are no absolute truths and ready solutions to everyday problems (McNamee, 2015a, 2015b; Ness \& Strong, 2013).

Social construction views learning as a collaborative and relational achievement. In this sense, knowledge is produced when people coordinate actions to produce communal meanings (Anderson, 2013; McNamee, 2015a). So, the notion of collaborative learning is fundamentally based on the idea that dialogue and collaboration are naturally transformative (Anderson, 2013). From this learning takes place through partnerships between people who come together for this purpose and it is assumed that when a transformation of meaning in conversation happens, it is a signal that a process of collaborative learning took place. Thus, it breaks with the dichotomy between the one who teaches and the one who learns, and everyone actively participates in the process from the conception to the evaluation, encompassing both its form and its content (Freire, 1987; McNamee, 2015a).

The study presented here is an analysis of a group process of learning inspired in the CEH policy, developed with professionals of a Brazilian public mental health service. The aim of this study is to understand how mental health professionals learn together in a CEH-process, identifying and understanding conversational transformations that occurred in the interactional process. Thus, this article will focus on the analysis of a critical moment, which configured in a generative moment, from a social constructionist perspective. 


\section{Method}

This is a qualitative and participatory research, built from an intervention, with explanatory focus (Gergen, 2014; Willig, 2005). It is guided by the social constructionist perspective, focusing on interactional and dialogical processes, considering language as a form of social action (Gergen, 2015; McNamee, 2014).

\section{Participants}

The participants are eight professionals: Paula, psychologist; Joseane, nurse; John, Cristina, Deborah and Eric, nursing assistants; Fernanda, social worker; and Franciele, nursing trainne - of a Psychosocial Care Center Type III (Portuguese acronym: CAPS III), located in a Brazilian city, who willingly accepted the invitation to participate. This invitation was made by the researcher in all public mental health services of the city, at the time of their usual team meetings. CAPS III was chosen because it was one of the services with more interested people in participate.

This service is a community center, with focus in day care and social rehabilitation, that also provides 24 hours care in intensive regimen for people with major mental disorders, offering a variety of activities and support promoted by 45 professionals of psychiatry, psychology, occupational therapy, social work, nursing and pharmacy. It has five permanent beds to be used for seven consecutive days or for ten discontinuous days in case of people needing continuous support. It also offers outpatient care that provides psychiatry and psychology consultations to people with minor disorders.

The CAPS III has a peculiar history because since its foundation, it worked primarily as an emergency unit through a period, supplying the lack of emergency service in the city. In 2015, year in which the data collecting was done, the service was undergoing a process of restructuring its activities, reassuming the work properly as a community service.

\section{Instruments}

The research was conducted from the composition of a closed group, that is with the same participants from start to end of the process, with whom five meetings inspired in CEH policy were realized. The number of meetings was carried out based on the scientific literature on group processes, in which five to eight meetings proved to be productive (Rasera, Oliveira \& Jesus, 2014) and considering the disponibility of participants. These meetings took shape as dialogue spaces organized around issues related to the daily work of the participants, in accordance with CEH policy.

\section{Procedure}

Data collection. The five meetings were conducted biweekly, during the work schedule of participants. They lasted one hour and thirty minutes and were facilitated by the first author of this text, in a social constructionist approach.
The meetings had no specific themes and the content of conversations was delimited by the group itself. The interventions of facilitator were based on the attempt to invite participants to critical reflection on practices in mental health. In this task, a Reflexive Record was produced by the facilitator in the interval between one encounter and another. The Reflexive Records consisted in a synthesis of the main subjects treated by the group, to build a memory about the encounters, and, at the same time, to promote reflexion and problematizations that could configure it in an interventional resource. This resource was read at the beginning of each meeting, but in a free way, without an obligation for the group to take it as the focus of discussion. For this, they had one page at maximum, so their reading would not take so long from the meeting. The Reflexive Records and the facilitation of the process were based fundamentally on three social constructionist guidelines to promote generative conversations, considering their connection with the $\mathrm{CEH}$ proposals: reflexivity, focus on potentiality, and concern about the relationship in group.

Reflexivity is related to the process of looking to daily practices critically, questioning certainties and usual practices, opening up to new meanings and possibilities. This is made possible using reflexive questions, which are those that insert adequately unusual differences in dialogue, that is, have the effect of making the familiar unfamiliar, and the ordinary unusual, expanding the possibilities of meaning (McNamee, 2015b). Propositions that set properly unusual differences are those which are not so different from the discursive universe of a person in a way that make it difficult for she/he understand, but that at the same time, are not so common in a way that not cause any destabilization of meanings.

The focus on potentiality is based in the principle that even in the contexts described as saturated by problems, important resources can still be identified. The social constructionist invitation to look to conversational practices as constructing realities leads to the appreciation of potentials rather than difficulties (Epston, White, \& Murray, 1992; Gergen et al., 2001).

Finally, the concern about the relationship in the group is about taking care of ways of relating within the group as a means to provide a dialogical context where different ideas and positions can coexist (Gergen et al., 2001; GuanaesLorenzi, 2015). In this sense, mutual respect, legitimacy and appreciation of all opinions, are aspects to be observed.

The conversations were audio-recorded and literally transcribed for analysis.

Data analysis. Data were analyzed from the focus on language, considering the notion of critical moments in the interaction. This notion is concerned with moments that are crucial to produce change: of direction, of conversation, of relationship, of assessment, of decision. They are like a moment of epiphany - or the possibility of reaching an epiphany - from a collective engagement in constructing some sense. Therefore, they are also called "Aha!" moments (Barret, 2004; Leary, 2004a; Menkel-Meadow, 2004). 
Literature points out that the definition of what is a critical moment is a complex task as there may be different interpretations by the participants, as well as different views about the possibility of identifying a critical moment (Barret, 2004; Green \& Wheeler, 2004; Leary, 2004a; MenkelMeadow, 2004).

The notion that guided this study is the notion of Barret (2004) and Leary (2004a) that point that it is only possible to identify a critical moment after it has occurred, from the interpretation of events that follow it. However, even from this retrospective notion, they consider that critical moments are events that can be triggered and leveraged by the facilitator to produce changes at any time. Barret (2004), in this sense, points out that critical moments are, ultimately, an interpretative construction.

Thus, taking as prerogative the researcher as a constructor of knowledge (Gergen, 2014), one critical moment was delimited considering the interpretation of the researcher that a significant process had occurred, based on the conversational process.

The delimitation of the critical moment was made based on the researcher's experience about the group process and the group's responsiveness to this moment, considering the emotions expressed and the greater engagement in the discussions; in the construction of the Reflexive Records; and, in the carefully reading and examination of transcriptions. With this, the researcher identified the critical moment and, from this, resumed elements that preceded it and succeeded it in terms of group processes. These elements are shown in edited excerpt of interaction that was constructed to give visibility to the interpretation made by researcher. In this way, the elements that preceded the critical moment justify, in a way, the construction of the intervention made by the facilitator; those that succeeded it, pointed, in a way, that a transformation on meanings had occurred.

\section{Ethical Considerations}

The research was approved by the responsible Committee in Ethics in Research (CAAE $\mathrm{n}^{\circ}$ 32777414.4.0000.5407). Informed consent was obtained for each study participant and confidentiality of all data was ensured by using fictional names.

\section{Results}

The five meetings were a complex process in which many complaints and problems were constructed in a saturated way. In addition, this process did not flow as planned and agreed previously with participants. During the five meetings, issues such as lack of participants and unforeseen in the service interfered in the implementation of the initially agreed schedule, resulting in the postponement of two meetings and the difficulty of reconciling new schedules with the entire group to extend it.

Moreover, most of the attempts to promote reflections made by the facilitator, based on what was considered as potential for transformation of meanings both in the interactive moment and in the Reflexive Records, did not resonate in this way to the group. So, conversations continued to revolve around the same problems, with the same suggestions, without significant transformations of meaning.

In this way, a critical moment occurred precisely from the facilitator's sharing of her feeling of standstill that the wide range of problems repeatedly discussed made her feel.

\section{Sharing the Feeling of Standstill: Moving the Focus to the Conversation}

This critical moment occurred in the fourth and penultimate meeting. To give visibility to its construction from the preceding meetings and interations, some interactions extracts will be shown. The first one occurred in the first meeting.

Eric: That was proposed, from there at the beginning, our excitement at the time was so great, do you remember, John? Everyone was so excited, even with the emergency focus, everything we are discussing today was all raised at that time. Equipment, structure, organizations of the service room, all this was widely spread at that time, was, was, discussed. Many ideas to change. . . but got lost in the rush of needing that the municipality had, in the lack of structure, and the service responded to this ...

Paula: .... it looks like two services in one, the ambulatory service, up there, and the semihospitalization, let's say in this way. It is as if it's two services (says it laughing), I feel also that there is a subdivision, because there, in the front, we have an ambulatory focus and up there, are the patients with whom we have a more daily contact ...

Eric: It's three services actually ...

Cristina: That's is what I was going to say ... !

Paula: The night schedule too, right?! (laughs)

Eric: We have the $24 \mathrm{~h}$ reception, the semihospitalization and the ambulatory.

Cristina: It's three in one! I was going to say that! (Edited excerpt of Meeting 1)

In this section the group discusses the difficulties arising from the different ways of organization of the service, remembering their plans and discutions in the period in which it functioned as a psychiatric emergency.

At meeting 2, these and other issues were discussed. The edited excerpt of interaction below give visibility to this, as well as to some attempts to reflection, made by the facilitator. 
Fernanda: Cristina put something very important, which I also think, that it is a big team, some people put the limits with the patients, but others do not put these limits, so I think it ends up messing up in deal with patients as Marcela. ... Another thing that also came to my mind and the staff is talking a lot, the importance of having a history of the patients ...

Gabriela: Would this record be a record of all the attendances made?

Fernanda: No, no!

Paula: It would be to have a summary of the patient's history. So, for example, if some patient of the semi-hospitalization asks to talk to me, sometimes I do not have any previous data from that patient summarized in the history.

Fernanda: Even life history! ...

Gabriela: I keep thinking that sometimes this is the kind of information that we indeed have in every contact, so, sometimes the person talks to Cristina, and then she knows something.

Paula: But that's the problem!

Gabriela: Ok ...

Paula: That everything is lost! It should have all the information /

Gabriela: Should have a way to put it together! ...

Paula: I'm thinking now, even the welcome record should be done, but with the patient who arrives, who, arrives at night, it is not done, we do not have this record. . .

Cristina: But it should be done!

Paula: So we have a flaw, because the record would already be a bit of this history, some relevant things, would already be on the welcome sheet....

Cristina: Exactly. And so, we don't know how the relationships are, between father and mother, right, father and daughter, mother and daughter, right, it's . . . how was the family before, right, because she was married, he died only three years ago, right? Yeah, we don't know what happened, right, with her mom and dad in their relationship that made Marcela act in this way ... (Edited excerpt from Meeting 2)
In this section, the group discusses a problem already mentioned in the previous meeting, which is the lack of continuity of actions between the teams of different turns of the service. They also point out as difficulties, the lack of systematization of information about each patient and his/her family relationships, which are placed as the cause of mental disorders. It is important to note that these issues were brought to conversation as complaints, not as relational requests, which would invite new agreements on practices and care.

In addition, it is possible to observe in the excerpt, an invitation to reflection, made by the facilitator, around the idea that the non-systematization of information would be something inherent to work in mental health care and in CAPS, which implies having new information for each contact. However, this problematization did not make sense for the group that considered this as the very cause of the lack of systematization of the information.

In the Reflexive Record about Meeting 2, according to the excerpt edited and presented below, it was proposed again, and, in other words, reflections related to this issue, inviting the participants to think about other alternatives of actions.

... We also spoke of the need for a detailed record of the patient's life history, which should be easily accessible to all professionals. In this regard, I wondered whether the anguish would be in relation to the lack of a systematized record or would be linked to the anxiety inherent in working with mental health, which requires us to sustain insecurity and transience. The impression I have is that every day we have more new informations about each case and maybe, this may give the impression that we never know enough to act. At the same time, I think that this non-systematized emergence of information is something characteristic of the complexity of life and mental health. What do you think about that?

We also talk about the team's perception that a patient's mother, because she is already exhausted, seems to want to stay away from her. I thought: how can we legitimize a family member's right to move away from a sick person when he/ she realizes that he/she cannot help and, on the contrary, is falling ill too? For a long time, mental health care consisted of removing the patient from the family and inserting him/her into asylums. Now, we have as principle the participation of the family in the treatment. But what about when the family does not want to live together with the patient?

Finally, I was thinking, in the face of the discussion about the search for causes and justifications for the behaviors and pathologies of patients, what would help us more: identify the causes 
or elaborate practical ways of dealing with each situation or person? (Excerpt from the Reflective Record of Meeting 2).

This record was read by the facilitator at the beginning of the third meeting, as usual, and was cited by Eric, as can be seen in the following excerpt, as an argument to support an idea opposed to that one the facilitator intended to invite them to reflect on.

Gabriela: And what remains to be done for Mrs. Zefa? What do you think needs to happen to her . .. to get better?

Eric: . . .I think we need to go forward, right, try to explore the possibilities. Try to peer into her inner universe that for a long time lay there, hidden, right?! Just behind the label of the disease, where people only saw the negative issues of the disease. . . You have pointed here (referring to the Reflexive Record), you put down here that for a long time the mental health care constituted in removing the patient from the family and imprisoning him/her in the asylum. This created a distance from the family, the family did not know how to handle with he or she, and when, when they were with the patient, with the person, they only saw that sick face, right, the sick behavior and the proposed therapies were others, right, never aimed to extract the best from the person, it was only based in isolation, right?!

Gabriela: U-hum.

Eric: And now, what happens now? Now that she's getting better, how will the family's willingness to explore it? ...

Franciele: They're already tired, right?!

Eric: That, that is, the way you put it here, because the family also gets sick, we know that the family gets sick too.

Gabriela: U-hum.

Cristina: How to rescue this family, right?! . . . That's difficult, right? Because, for example, if Mrs. Zefa's family does not give her this support, she will not be able to stay stabilized. And we will not be able to exploit what else can be improved in her.

Gabriela: One thing that is getting very strong for me is a contratidion with the idea that the family should be a resource, right, so it could be the patient's support, to maintain stabilization and be a source for further improvement. But when the family is not this resource, it seems that there is nothing else to do.

Franciele: U-hum.

Gabriela: But we have to have something to do (says laughing), we have to think about what to do when we count on the other, but the other does not do what we expected. So, we have to think about what we're going to do about it.

Cristina: So, this is a big problem. But there's a classic case, Claudia, right? Who does not have any family.

Joseane: Yeah, that's what I was going to say, I think when they have a family, it's a challenge for us, but I still see it with good eyes. Worse is the patient who has no family or when he/she has a family member who is also schizophrenic . . . . (Edited excerpt of Meeting 3).

In this section, the group discusses possibilities of care for a patient after medication remission of symptoms. In doing so, they construct the non-adherence of the family as the main reason for the difficulties in following up the patient's treatment.

As can be seen, the Reflective Record of Meeting 2 is cited to support the idea of responsibility and non-adherence of family members, unlike that intended by the facilitator.

In conversational process, the facilitator tries to problematize the notion of non-adherence and the unique responsibility of the family, inviting them to think about other possibilities for action by the team itself. This invitation, however, cannot also be accepted, whereas the professionals change the direction of the subject to a problem even more complex, in their opinion, that would be the patients who do not have family.

In the Reflective Record of Meeting 3, the facilitador tried once again to invite participants to reflect on these aspects, as can be seen below.

... I think that this idea of the family as responsible for the patient leaves health professionals in a circular logic that has no way out: we take the family as cause and also as fundamental for care, in a way that we are disempowered in our role of caring.

I think all families have resources to deal with their difficulties, but perhaps we are looking at them with the lenses of such a "normality" so that some of these features seem to be more a symptom than a resource. Don't you think this notion of family "normality" need to be reviewed? How can we value what the family already does? 
For this, it may be important to think: What other notions of mental illness and treatment would help us to see the resources of the family? What other senses of family and social network would enable us with more resources to produce care in CAPS III? . . . (Excerpt from the Reflective Record of Meeting 3).

In this Reflective Record, the intention was to invite participants to change the focus to their practices, seeking to construct alternative ways of promoting care, besides betting on the responsibility of the family. However, this Record was not taken for reflection by the group in Meeting 4.

In this meeting, the group resumed the discussion of issues that had already been repeated in the previous meetings. From this, the facilitador shared with the group her feeling of deadlock on the locked conversations, which culminated in the critical moment delimited, which is considered as an openness to reflection and collaborative learning.

Eric: I still, I still insist on that issue of a directed work, I think it is needed a more focused attention on her issue (says referring to Mrs. Zefa; Paula says at the same time: a more individualized attention?). ... .

Cristina: But I think she is that way because people anticipated her and thought she did not have the capacity. . . . No one seems to respect her time. They just come and talk like that "You cannot do it! You cannot do that! That's wrong! “

Eric: So she become like a disciple, it is like she is always a trouble, that is, Mrs. Zefa is a nuisance to her family ...

Paula: It reminded me one thing too ... we do not have this information on a daily basis, I feel that here, on a daily basis, information about family, about people, are very fragmented, then it's as if we've lost it in the middle of the way. . .

Gabriela: I don't know, I'm hearing you, I'm with such a feeling ... it looks like a . . . a sense of standstill ... . what can we do, you know? I'm with this feeling. . . . It seems so much challenge that oh my God! How can we try to improve it a little bit? It's a lot of things, it is very complex, you were bringing, ah . . . many issues that were getting more complicated, so, you know, we think "no, this I can do", but the family doesn't come, "so, that I can do", and comes a "no" again! It seems that everything has an impeditive, and then I'm like in this position, I'm with this feeling, so I'm sharing to you to know if (John starts to answer: we ... ) it is more like a thing that is mine or if it makes sense to the group, I don't know.
John: We already passed, we already talked about it many times here in CAPS (Gabriela says: I imagine ... ) and sometimes, we talked about that in meetings, that would be interesting to us to try to improve a condition or seek a solution at each time, in a punctual way. (Gabriela says: Uh?!) For example, you work with that person, try to see what you can do with her/him, because if we put everybody together, ah, every day we have a new thing to solve. So we end up banging our heads, the new demands keep coming and we end up not solving the other that we had had as a goal. . . .

Paula: But I think it's two different things, there is this dynamic that demands no stop, so when we're trying to solve something, five others appear.

John: Ten others!

Paula: You're right! But in the other hand, sometimes we have difficulty in finishing what we start as well.

Cristina: But ...

John: We don't even know if we could finish it!

Cristina: I agree!

Paula: By finalizing, I mean give it a solution at least for a while, in that time, but I know that there are things that we can't solve, I think. Some we can, some we cannot, right?! (John: yeah . . .) So we stay with this feeling of not being able to finish, we think about many points that need attention and just stop, don't do it! We don't systematize!

Deborah: It cause us anxiety!

John: So, you know, you had an accurate perception! You had an accurate perception!

Cristina: So, for me, in my opinion, I think we still don't have the energy to do all the things, we have the vision but not resources to do all this.

Gabriela: U-hum.

Cristina: Because for you to do certain things, I think, you would need to know deeply your patient. How can you do this? ... Are information fragmented? Yes, they are. Why? ... For example, for you to know a patient, you meet a patient, he says something for you here, then he goes for his appointment with you, Paula, and he tells you many things, in your therapeutic setting, can you tell this for us? No! Do you understand me?! 
Paula: As a work team ...

\section{Cristina: Ah?}

Paula: What is relevant for work team, I can tell, actually.

Eric: Yes, she can!

Paula: What is relevant to continue our work, selecting some information, I can!

John: As was the case of Francisca.

Paula: And as it was with Roberta another day. She had a perception and came to me to tell me, because she knew that I was taking care of the case, to know if she was on the right path. Something that respects some ethical limits. The way we work here, we cannot work together and start to think individually, we need to start to think in a collective secrecy, of course that I don't need to disclosure the patient life in details, but if we want to do a good work, some information is necessary, my criteria is which information is necessary for the team continue work with this patient? Then, I don't need to detail, this I'm trying to share, do you understand me? (Edited excerpt of Meeting 4).

In the passage cited, facing the group discussion of problems already repeatedly discussed, the facilitador shared her feeling and evaluation that the group was paralyzed in a cycle of problems without solutions. With that, in a way that still repeat a movement of other meetings, her feeling is at first moment considered something that had already been examined in previus conversations of the group, not generating changes or solutions. Then, Paula proposes the differentiation between the high demand of the service and the difficulty of the group to put into practice what they discuss and decide in their meetings. From this, the facilitator's feeling becomes something shared with Paula and the group initiates a process of analysis that not only in the CEH meetings, carried out for this research, but in all other meetings held in the service, there was this difficulty in move on to what had been discussed.

In the passage, this evaluation does not seem to be shared by Cristina, who proposes an explanation for the group's failure to follow the discussions made at meetings, bringing again the issue of fragmentation of information. However, exploring her perception, she mentions an example of the difficulty with sharing information about patients due to the requirement of professional secrecy in the health area. From this, Eric, John, and especially Paula, engage in explaining to Cristina how notions of professional secrecy could be revised to fit interdisciplinary team practices.

With this, it is possible to see that in the conversational process, the sharing of feeling by the facilitator had the effect of inviting the group to examine how they were experiencing the moments of group meetings, enabling a conversation about the dialogue. So, it made possible, also, a conversation about something that could be improved by the group, even with all service challenges: the sharing of information from a collective secrecy logic.

This example makes possible to recognize a process of collaborative learning, as a relational achievement through dialogue. From the conversation about everyday challenges, the group got in touch with feelings arising from their difficulty to put into practice their plans and strategies and, from the examination of this difficulty, it has become possible to identify an issue that the group was able to clarify and dissolve at that moment.

This moviment of reflection about the way they engage in their meetings reverberated at the next meeting, the last of the process.

John: . . . I, in particular, sometimes point out that our afternoon meetings have not been very productive, considering the consequences of what is dealt with, not the moment of discussion itself, because this is very valid, people together in dialogue. So, our group meetings, I feel that they do not give the positive result that I hope, that I expect to be fulfilled of what was agreed (Gabriela says at the same time: u-hum.), so I make this distinction. (Gabriela says at the same time: u-hum.)....

Paula: Even the meeting schedule I think it was a bit loose, you know, some days had to be canceled and when the interval between meeting was large, it contributes to cool down the decisions, right. (Gabriela says at the same time: u-hum.). In that sense, which is also one of the difficulties that we have with our current meetings that happen here, especially in the shift of afternoon, this ends up also cooling down, you know, these interruptions, this difficulty with the schedule.

Gabriela: U-hum. So institutionalizing a schedule, do you think is an important thing?

Paula: I think, but theoretically, we already have this institucionalized, but in practice, it does not always happen ... I was thinking a lot about the physical changes proposed in the last meeting, Emilia and I were trying to organize the reception. And then everyone had an idea, and then there's a very big movement of change, but it starts like that "this does not work, that does not work" and I see that sometimes it is like throwing cold water (says laughing) (Eric says at the same time: this is very common!). . . .

John: If you cannot change physical things, a chair, you know ... And then imagine talking 
about subjective things, that the proposal of the service here is to promote activities, not only accommodation....

Paula: That's what I'm talking about, I think, listening to John, it's not enough for us to have the moment of change, there's something catching us and it's paralyzing. We have to have the impetus of change about five times (she laughs and Gabriela laughs) to see if something happens! (Edited excerpt of Meeting 5).

In this section the group talks about their dissatisfaction with the progress and referral of their current meetings held in the service, continuing the conversation initiated at the previous meeting and reinforcing a shared perception of the feeling of paralysis. From this, even the faults and delays of the CEH meetings were examined as part of this standstill.

In this way, it indicates that the critical moment was significant for the group and that it promoted a transformative effect on the conversation.

\section{Discussion}

The analysis presented here shows that it is possible to identify tranformations in meanings and collaborative learning even when the conversation seems very saturated by problems. Social constructionism was a useful approach to highlight these achievements, as it enables an analysis from dialogues, considering the potential of meaning and action made possible by conversation (McNamee, 2015a).

To this task, the identification of a critical moment as a resource for analysis of the group process/conversational process was useful, because it is a way to look at processes that enable identify small but important movements of change.

In this way, the facilitator's sharing of her paralyzing feeling had a transformative effect on the conversation, as it put in the centre of discussion the conversations itself, instead of focusing on problems that were beyond the participants' possibilities of action at the moment. Recognize and deal with the perception that the group is trapped in an unproductive cycle of using the same old arguments and solutions is a guidance for the construction of generative moments (Green \& Wheeler, 2004). This is also an invitation to engage in relationally reflexive inquiry, which means taking the conversation itself as an object of reflection, what is proposed by McNamee and Gergen (1999) as a means to promote relational responsibility.

At the same time, this intervention was also a discursive recognition by the facilitador that the problems that they had been discussing were indeed important challenges. In doing so, the facilitator was responsive to the group needs.

From this, other developments could be possible with the group if the process could have been continued. Once we had the opening to talk about the functioning of the group meetings, some problematizing reflections might find resonance in the group if the meetings were not subscribed to the research and were continued. However, even with this possibility it would be important to consider the limitation of the reflections and resources proposed.

As shown, the group had a pattern of discussing looking for causal explanations, based on the modern logic of understanding that, to solve problems, one must seek the causes and then work out their solutions. Thus, the reflections considered relevant was that related to the diagnosis and the causes of the disorders. The reflexive questions made by the facilitator, in this way, configured in inadequately unusual differences for the group, at that moment, not contributing to expand the possibilities of meaning and action. In addition, although the facilitator's questions sought to broaden the conversation, there was a need and demand from the group for talking about the difficulties of their daily lives, and not responding to that demand at that moment was to fail to be responsive and not corroborating dialogic communicationt.

Furthermore, meaning is a relational achievement (Gergen, 2015), so the facilitator's speech is not significant in itself, and does not determine alone the flow of the conversation. Hence the importance of an analysis such as this, which involves overlaying identification of critical moments retrospectively, so it is possible to imagine ways to prepare the facilitator of CEH-process for improvisation in interaction with groups and highlight small movements in transformation of meanings. As Leary (2004b) points it, the task of mediating occurs in a dialogic tension between what is possible to know and the unpredictability of what come next.

Another important issue is about the effectiveness of this kind of educational process in affect the lives of participants outside the meetings. As social constructionist presume that practices are based on a dialogical ethics which include different voices and multiple meanings, CEH practices enable participants to expand their repertoires of themselves and of their practices (Moscheta et al., 2015). This means that however there is no guarantee that the meanings that had been helpful in promoting transformations in a context of CEH practice will be expanded to other contexts, dialogue gives the basis for participants bring the different voices and discourses that emerge in the interactive process to various situations outside the immediate interaction.

\section{References}

Amarante, P. (2015). Teoria e crítica em saúde mental: Escritos selecionados [Theory and criticism in mental health: Selected writings]. São Paulo, SP: Zagodoni.

Anderson, H. (2013). Collaborative learning communities: A postmodern perspective on teaching and learning. In B. J. Irby, G. Brown, R. Lara-Alecio, \& S. Jackson (Eds.), The handbook of educational theories (pp. 515-527). Charlotte, NC: Information Age.

Barret, F. J. (2004). Critical moments as change in negotiation. Negotiation Journal, 20(2), 213-219. doi:10.1111/j.1571-9979.2004.00018.x 
Campos, G. W. S. (2015). Um método para análise e cogestão de coletivos [A method for analysis and comanagement of collectives] (5o ed). SãoPaulo: Hucitec.

Campos, R. O. (2001). Clínica: A palavra negada - sobre as práticas clínicas nos serviços substitutivos de saúde mental [Clinical practice: Denied words - on clinical practices in mental health substitutive services]. Saúde em Debate, 25(58), 98-111. Retrieved from http:// www.fcm.unicamp.br/fcm/sites/default/files/paganex/ rosana2001clinicaapalavranegada.pdf

Ceccim, R. B. (2010). A educação permanente em saúde e as questões permanentes à formação em saúde mental [The permanent education in health and the permanent issues to the formation in mental health]. Caderno Saúde Mental, (3), 67-90. Retrieved from http://www.esp. mg.gov.br/wp-content/uploads/2011/02/caderno_SM3 Os_desafios_da_formacao.pdf

Ceccim, R. B., \& Feuerwerker, L. C. (2004). O quadrilátero da formação para a área da saúde: Ensino, gestão, atenção e controle social [The quadrilateral of formation for the health area: Teaching, management, attention and social control]. Physis, 14(1), 41-65. doi:10.1590/S010373312004000100004

Davini, M. C. (1995). Educación permanente en salud [Continuing education in health]. Washington, DC: Organización Panamericana de la Salud. Retrieved from http://apps.who.int/iris/bitstream/10665/173954/1/ Educacion\%20permanente\%20en\%20salud.pdf

Desviat, M. (2011). Panorama internacional de la reforma psiquiátrica [International overview of psychiatric reform]. Ciência \& Saúde Coletiva, 16(12), 4615-4622. doi:10.1590/S1413-81232011001300010

Epston, D., White, M., \& Murray, K. (1992). A proposal for a re-authoring therapy: Rose's revisioning of her life and a commentary. In S. McNamee \& K. J. Gergen (Eds.), Therapy as social construction (pp. 96-115). Thousand Oaks, CA: Sage.

Freire, P. (1987). Pedagogia do oprimido [Pedagogy of the oppressed] (17th ed.). Rio de Janeiro, RJ: Paz e Terra.

Gergen, K. J. (2014). Pursuing excellence in qualitative inquiry. Qualitative Psychology, 1(1), 49-60. doi:10.1037/ qup0000002

Gergen, K. J. (2015). An invitatin to social construction (3rd ed.). London, United Kingdom: Sage.

Gergen, K. J., McNamee, S., \& Barrett, F. J. (2001). Toward transformative dialogue. International Journal of Public Administration, 24(7-8), 697-707. doi:10.1081/PAD100104770

Gergen, K. J., \& Ness, O. (2016). Therapeutic practice as social construction. In M. O'Reilly \& J. N. Lester (Eds.), The Palgrave handbook of adult mental health: Discourse and conversation studies (pp. 502-519). London, United Kingdom: Palgrave Macmillan.
Gigante, R. L., \& Campos, G. W. S. (2016). Política de formação e educação permanente em saúde no Brasil: Bases legais e referências teóricas [Continuing training and education in health policy in Brazil: Legal basis and theoretical referencess]. Trabalho, Educação e Saúde, 14(3), 747-763. doi:10.1590/19817746-sip00124

Green, G. M., \& Wheeler, M. (2004). Awareness and action in critical moments. Negotiation Journal, 20(2), 349364. doi:10.1111/j.1571-9979.2004.00028.x

Guanaes-Lorenzi, C. (2015). From working with groups to working as a group: Reflections of group practice in the family health strategy. In E. F. Rasera (Ed.), Social constructionist perspectives on group work (pp. 41-50). Chagrin Falls, OH: Toas Institute.

Leary, K. (2004a). Critical moments in negotiation. Negotiation Journal, 20(2), 143-145. doi:10.1111/j.15719979.2004.00012.x

Leary, K. (2004b). Critical moments as relational moments: The centre for humanitarian dialogue and the conflict in Aceh, Indonesia. Negotiation Journal, 20(2), 311-338. doi:10.1111/j.1571-9979.2004.00025.x

McNamee, S. (2014). Research as relational practice: Exploring modes of inquiry. In G. Simon \& A. Chard (Eds.), Systemic inquiry: Innovations in reflexive practice research (pp. 74-94). London, United Kingdom: Everything is Connected Press.

McNamee, S. (2015a). Evaluation in a relational key. In T. Dragonas, K. J. Gergen, S. McNamee, \& E. Tseliou (Eds.), Education as social construction: Contributions to theory, research and practice (pp. 336-349). Chagrin Falls, OH: Taos Institute.

McNamee, S. (2015b). Practitioners as people: Dialogic encounters for transformation. Metalogos, (28), 1-25. Retrieved from https://mypages.unh.edu/sites/default/files/ sheilamcnamee/files/practitioners_as_people_metalogos.pdf

McNamee, S., \& Gergen, K. J. (1999). Relational Responsibility: Resources for Sustainable Dialogue. London: Sage.

Menkel-Meadow, C. (2004). Critical moments in negotiation: Implications for research, pedagogy, and practice. Negotiation Journal, 20(2), 341-347. doi:10.1111/j.15719979.2004.00027.x

Ministério da Saúde. Secretaria de Gestão do Trabalho e da Educação na Saúde. Departamento de Gestão da Educação em Saúde. (2009). Política nacional de educação permanente em saúde [National policy of continuing education in health]. Brasília, DF: Autor. Retrieved from http://portal. anvisa.gov.br/documents/33856/396770/Pol\%C3\%ADtica+Nacional+de+Educa $\% \mathrm{C} 3 \% \mathrm{~A} 7 \% \mathrm{C} 3 \% \mathrm{~A} 3 \mathrm{o}+$ Permanente+em+Sa\%C3\%BAde/c92db117-e170-45e 7-9984$8 \mathrm{a} 7 \mathrm{cdb} 111 \mathrm{faa}$ 
Moscheta, M. S., Souza, L. V., \& Corradi-Webster, C. M. (2015). Social constructionist resources for investigating and work with groups in healthcare. In E. F. Rasera (Ed.), Social construcionist perspectives on group work (pp. 177-185). Chagrin Falls, OH: Taos Institute.

Ness, O., \& Strong, T. (2013). Learning new ideas and practices together: A cooperative inquiry. Journal of Family Psychotherapy, 24(3), 246-260. doi:10.1080/089 75353.2013.817268

Pinto, H. A., Ferla, A. A., Ceccim, R. B., Florêncio, A. R., Matos, I. B., Barbosa, M. G., ... Zortea, A. P. (2014). Atenção básica e educação permanente em saúde: Cenário apontado pelo Programa Nacional de Melhoria do Acesso e da Qualidade da Atenção Básica (PMAQ-AB) [Primary care and continuing health education: Scenario appointed by the National Program for Access and Quality Improvement in Primary Care (PMAQ-AB)]. Divulgação em Saúde para Debate, (51), 145-160. Retrieved from http://cebes.org.br/ site/wp-content/uploads/2014/12/Divulgacao-51.pdf

Pitta, A. M. F. (2011). Um balanço da reforma psiquiátrica brasileira: Instituições, atores e políticas [An assessment of Brazilian psychiatric reform: Institutions, actors and policies]. Ciência \& Saúde Coletiva, 16(12), 4579-4589. doi:10.1590/S1413-81232011001300002

Rasera, E. F., Oliveira, F. M., \& Jesus, M. J. B. S. (2014). A prática grupal e o discurso sobre a ética em documentos oficiais [Group work and the discourse of ethics in official documents]. Estudos de Psicologia (Campinas), 31(3), 405-414. doi: 10.1590/0103-166X2014000300009

Stroschein, K. A., \& Zocche, D. A. A. (2011). Educação permanente nos serviços de saúde: Um estudo sobre as experiências realizadas no Brasil [Permanent education in health services: A study on the experience gained in Brazil]. Trabalho, Educação e Saúde, 9(3), 505-519. doi:10.1590/S1981-77462011000300009

Turco, M. G., \& Baron, R. B. (2016). Observations on the 2016 World Congress on Continuing Professional Development: Advancing learning and care in the health professions. The Journal of Continuing Education in the Health Profession, 36(Suppl. 1), S4-7. doi:10.1097/ CEH.0000000000000106

Willig, C. (2005). Introducing qualitative research in psychology. Buckingham, United Kingdom: Open University Press.
Gabriela Martins Silva holds a Ph.D. from the Faculdade de Filosofia, Ciências e Letras de Ribeirão Preto at Universidade de São Paulo, Ribeirão Preto-SP, Brazil.

Ottar Ness is a Professor at Norwegian University of Science and Technology, Trondheim, Norway.

Carla Guanaes-Lorenzi is a Professor of the Faculdade de Filosofia, Ciências e Letras de Ribeirão Preto at Universidade de São Paulo, Ribeirão Preto-SP, Brazil.

\section{Authors' Contribution:}

All authors made substantial contributions to the conception and design of this study, to data analysis and interpretation, and to the manuscript revision and approval of the final version. All the authors assume public responsability for content of the manuscript.

Received: Dec. 09, 2016

1st Revision: Jun. 01, 2017

2nd Revision: Oct. 31, 2017

Approved: Mar. 20, 2018

How to cite this article:

Silva, G. M., Ness, O., \& Guanaes-Lorenzi, C. (2018). Continuing education in mental health: Critical moments to analyze group process. Paidéia (Ribeirão Preto), 28, e2834. doi: http://dx.doi.org/10.1590/1982-4327e2834 